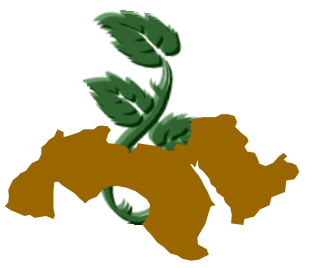

Arab Univ.

J. Agric. Sci., Ain Shams Univ., Cairo, 23(1), 101 - 109, 2015

\title{
EFFECT OF SOLAR UV RADIATION ON ANTIOXIDANT ENZYMES AND PHENOLS BIOSYNTHESIS IN LETTUCE (Lactuca sativa)
}

\author{
Mervat A.R. Ibrahim ${ }^{1}$ and Hany A.M. Srour ${ }^{1}$ \\ 1- Biochemistry Department, Faculty of Agriculture, Ain Shams University, 68 Hadayek \\ Shoubra, PO 11241 Cairo, Egypt
}

Keywords: UV radiation, lettuce (Lactuca sativa), Peroxidase, catalase, Ascorbate peroxidase, phenolic compounds, phenyl alanine ammonia lyase

\section{ABSTRACT}

This study aims to evaluate the effect of solar UV radiation on defensive enzymes activities in lettuce seedlings. Seeds of lettuce were grown in high tunnels for 35 days, exposed to three different levels of solar UV, created by using three different types of plastic films. Each plastic film transmits different levels of solar UV $(0 \%$ in UV-B, $4 \%$ in UV$\mathrm{L}$ and $83 \%$ in UV-T). The obtained results indicated that solar UV radiation has led to significant decrease in seedling fresh weight. UV-B treatment resulted the highest shoot and root length while UV-T treatments exhibited the highest shoot: root ratio. Solar UV radiations have no effect on peroxidase activity in shoots. While ascorbate peroxidase was activated and catalase was inhibited in shoot by UV-T treatments. In lettuce roots, peroxidase, ascorbate peroxidase, and catalase activities were increased by increasing the level of solar UV radiation. In case of UV-T, phenylalanine ammonia lyase (PAL) activity in both shoots and roots of lettuce seedlings was higher than those of other treatments. In addition, Phenols are accumulated in lettuce shoots as a result of UV radiation in UV-L and UV-T treatments. Also, phenols in roots increased by increasing solar UV dose. The study concluded that solar UV radiation induced some antioxidant enzymes, increased the accumulation and biosynthesis of phenolic compounds and reduced lettuce seedlings growth.

\section{INTRODUCTION}

Depletion of stratospheric ozone layer is leading to an increase in UV radiation reaching the earth's surface. Egypt is exposed to a high level of solar UV radiation due to its geographical position. Although, UV is only a minor component of solar radiation its potential to cause biological effects on plants is higher than any other radiations due to its high energy. In recent years, there have been number of studies highlighting the molecular mechanism by which UV can affect plant physiology and various biochemical processes. The most common effects of UV radiation on plant physiology include, change in plant growth and development, decrease the photosynthetic activity and changes in pigment composition and enzyme activities (Soheila and Mackerness, 2000; Morales et al 2011). Krizek et al (1998) reported that lettuce plants grown in the absence of solar UV-B radiation had greater fresh and dry weight of tops, roots and stems than that of those grown under ambient UV-B. Also, Rao et al (1996) reported that irradiation Arabidopsis thaliana with UV-B modified the activities of various antioxidant enzymes such as superoxide dismutase, peroxidase, catalase, glutathione reductase, and ascorbate peroxidase.

In further investigation, García-Macías et al (2007) found that exposure of lettuce seedlings to high levels of UV radiation during cultivation caused the leaves to redden and increased concentrations of total phenols and the main flavo- 
noids (quercetin and cyanidin glycoside) as well as luteolin conjugates and phenolic acids. The total phenol content increased from $1.6 \mathrm{mg}$ gallic acid equivalents per gram (GAE/g) of fresh weight (FW), for lettuce grown under UV block film to 2.9 and $3.5 \mathrm{mg}$ as GAE/g of FW, for lettuce grown under the UV low and UV window films. In addition, the antioxidant activity was also higher in lettuce exposed to higher levels of UV radiation. The content of phenolic acids, as caffeic acid, was affected by the level of UV that penetrated through the plastic cover films. Flavonoid glycosides were formed in lettuce seedlings, due to exposure to high levels of UV radiation, as demonstrated by the concentrations of aglycones after hydrolysis. These results showed the potential of the use of UV-transparent plastic as a means of increasing beneficial flavonoid content of red leaf lettuce when the crop is grown in polytunnels.

The present study aims to clarify how the different levels of solar UV radiation can affect the growth and plant morphology of red lettuce and to test its effects on antioxidant defensive enzymes as well as investigates the effects of different doses of solar UV- radiation on phenols biosynthesis enzyme, PAL, and the accumulation of phenolic compounds in lettuce seedlings.

\section{MATERIAL AND METHODS}

\section{Plant growth and treatments}

Seeds of red lettuce, Lactuca sativa, were grown in three open-sided tunnels $(6.5 \times 40 \mathrm{~m})$ covered with three different films at Wadi El Natroon, Behera, Egypt. The spectral properties of the films were as previously reported (GarciaMacias et al 2007). All three films contained the infra-red reducing and light diffusing components of Luminance THB (British Polythene Industries PLC, Greenock, UK). These three films have similar thickness of 180 microns and similar transmission of photosynthetic active radiation $400-700 \mathrm{~nm}$ .Plastic covers transmit different levels of UV solar radiation as follow:

- The first cover transmitted only $4 \%$ of solar UV and is named low UV transmitted film (UV-L)

- The second transmitted $83 \%$ of solar UV (260$400 \mathrm{~nm}$ ) and is named UV transmitted film (UV-T).

- The third film blocked all solar UV radiation below $380 \mathrm{~nm}$ and is named UV-B.

After 35 days of sowing, lettuce seedlings samples were collected. Shoots and roots lengths were measured and then samples were kept at - $20^{\circ} \mathrm{C}$ and used for enzymes analysis and phenols determination.

\section{Determination of total phenols}

Phenolic compounds were extracted from plant tissue with ethanol $80 \%$. The phenolic compounds were determined by using folin solution according to the method described by Danial and George (1972), and recommended by AOAC, (2000). The phenolic compound contents were expressed as $\mathrm{mg} / \mathrm{g}$ (D.W.).

Determination of antioxidant defensive en-
zymes and soluble proteins

\section{Preparation of enzymes crude extract}

Fresh plant samples were homogenized in 100 $\mathrm{mM}$ chilled sodium phosphate buffer ( $\mathrm{pH} 7.0)$ containing $0.1 \mathrm{mM}$ EDTA and $1 \%$ polyvinylpyrrolidone (PVP) $(\mathrm{w} / \mathrm{v})$ at $4^{\circ} \mathrm{C}$. The extraction ratio was $4 \mathrm{ml}$ buffer for each one gram of plant material. Homogenate was centrifuged at $15.000 \mathrm{~g}$ for $15 \mathrm{~min}$ at $4^{\circ} \mathrm{C}$. Supernatant was used to measure the enzymes' activities. The soluble protein content in supernatant was measured according to Lowry et al (1951) and using bovine serum albumin (BSA) as standard.

\section{Assay of peroxidase (PX) activity}

Peroxidase (E.C 1.11.1.7) activity in enzyme extract was determined as described by Hammer Schmidt et al (1982). The reaction mixture $3 \mathrm{~mL}$ consisted of $0.25 \%(\mathrm{~V} / \mathrm{V})$ guiacol in $10 \mathrm{mM}$ sodium phosphate buffer pH 6.0 containing $10 \mathrm{mM} \mathrm{H}_{2} \mathrm{O}_{2}$. Volume of $25 \mu$ l of the crude enzyme extract was added to initiate the reaction. The developed color was measured calorimetrically at $470 \mathrm{~nm}$. The specific activity expressed as $\Delta \mathrm{OD} \cdot \mathrm{min}^{-1} \cdot \mathrm{mg}^{-1}$ protein.

\section{Assay of catalase (CAT) activity.}

Activity of catalase (E.C 1.11.1.6) was determined using a modified method developed by $\mathbf{A e}-$ by (1984). A reaction mixture of $3 \mathrm{~mL}$ contained 10 $\mathrm{mM} \mathrm{H}_{2} \mathrm{O}_{2}$ and $100 \mu \mathrm{l}$ of enzyme extract in $50 \mathrm{mM}$ phosphate buffer (pH 7.0). Enzyme activity was assayed by monitoring the decrease in absorbance at $240 \mathrm{~nm}$ as a consequence of $\mathrm{H}_{2} \mathrm{O}_{2}$ consumption. One unit of CAT activity $(U)$ was defined as the decomposition of $1 \mu \mathrm{mol} \mathrm{H}_{2} \mathrm{O}_{2}$ per minute. 


\section{Assay of ascorbate peroxidase (APX) activity}

The activity of ASP (E.c 1.11.1.11) was measured according to Nakano and Asada, (1981). The assay mixture $3 \mathrm{ml}$ consisted of $0.5 \mathrm{mM}$ Ascorbic acid, $0.1 \mathrm{mM} \mathrm{H} 2 \mathrm{O} 2,0.1 \mathrm{mM}$ EDTA, 50 $\mathrm{mM}$ sodium phosphate buffer ( $\mathrm{pH} 7.0)$, and 100 $\mu \mathrm{L}$ enzyme extract. Ascorbate peroxidase activity was expressed as a decrease in absorbance at $290 \mathrm{~nm}$ for $1 \mathrm{~min}$.

\section{Determination of Lipid peroxidation}

The level of lipid peroxidation was measured by determination of malondialdhyde (MDA) in plant tissues as described by Heath and Packer (1968). One gram of tissue (FW) was homogenized in $5 \mathrm{ml}$ of TCA $0.1 \%(\mathrm{~W} / \mathrm{V})$. The homogenate was centrifuged at $10000 \mathrm{~g}$ for $5 \mathrm{~min}$, then $4 \mathrm{ml}$ thiobarbituric acid $(0.5 \%$ in TCA $20 \%)$ was added to $1 \mathrm{ml}$ of the supernatant. The mixture was heated at $95^{\circ} \mathrm{C}$ for $30 \mathrm{~min}$ and then quickly cooled in ice. The contents were centrifuged at $10000 \mathrm{~g}$ for $15 \mathrm{~min}$ and the absorbance was calculated using a extinction coefficient of $155 \mathrm{mM}-1 \mathrm{~cm}-1$. MDA content expressed as $\mu \mathrm{mol} / \mathrm{g}$ (FW).

\section{Assay of phenylalanine ammonia lyase activity}

The activity of phenylalanine ammonia lyase (PAL EC.4.3.1.5) was assayed by the method described by $\mathrm{He}$ et al (2001). PAL assay reaction consisted of $100 \mu \mathrm{L}$ crude enzyme extract and 900 $\mu \mathrm{L}$ of $6 \mathrm{mM}$ phenylalanine, $500 \mathrm{mM}$ tris- $\mathrm{HCl}$ buffer $(\mathrm{pH} 8.5)$. The mixture was incubated at $37^{\circ} \mathrm{C}$ for one hour. Then, the absorbance of the reaction mixture was spectrophotometrically measured at $290 \mathrm{~nm}$. The amount of trans-cinnamic acid formed was determined by comparison of absorbance with a standard curve of trans-cinnamic acid. PAL activity was expressed as $\mu \mathrm{mol}$ cinnamic acid $\mathrm{h}^{-1} \cdot \mathrm{mg}^{-1}$ protein.

\section{Statistical Analysis}

The results presented are the means \pm standard deviation of five replicates. The recorded data were treated statistically using the one way analysis of variance as described by SAS (1996). The means were compared by Least Significant Difference test at $p<0.05$.

\section{RESULTS AND DISCUSSIONS}

\section{UV radiations reduce plant growth}

Figure (1) showed that shielding of solar UV transmission by plastic films caused activation of both root and shoot growth in lettuce seedlings. The results clearly indicated that lettuce seedlings exposed to high level of solar UV radiation have a small red leaves, as shown in UV-T treatment, compared to green leaves with low level of red color in lettuce seedlings exposed to low level of solar UV. Table (1) showed root and shoot lengths of lettuce seedlings grown in commercial greenhouses covered with different UV transmitting plastic films. The seedling grown under UV blocker plastic showed the longest shoot and root length and seedling fresh weight. While seedlings grown under high level of UV solar radiation showed the shortest shoot and root length and lowest seedling fresh weight. The observed growth reduction of root and shoot in lettuce seedlings exposed to high level of solar radiation could explained by damaging effects of UV solar radiations on DNA. In addition, direct UV-B effects on the growth regulators of the gibberellins family may lead indirectly to suppression of root and shoot growth by decomposition of gibberellins, as was shown for Hyoscyamus niger (Rau and Hoffmann, 1988).

Attenuation studies conducted with crop plant species and cultivars grown in commercial greenhouses covered with differently UV-transmitting plastic foils simulating a solar UV-difference of about 10 to $15 \%$ also showed reductions in stem growth and leaf area of four bush bean cultivars during their early development under higher solar UV-B (Saile-Mark and Tevini, 1997). In those studies it was shown that flowering delay of bean and maize plants was cultivar dependent (Mark and Tevini, 1996). As a consequence of growth reductions and flowering suppression number and weight of pods and therefore yield of bean fruits was reduced at the higher UV-B level. Similar results have been obtained for pea fruits $\mathrm{mdBrassica}$ nigra seeds (Conner and Zangori, 1997; Corlett et al 1997), whereas seed production in Mentha spicata and the Mediterranean shrub Cistus creticus was increased by enhancement of UV-B (Gram-matikopoulos et al 1998).

\section{Solar UV radiation induces lipid peroxidations}

Table (2) showed that the level of lipid peroxidation significantly increased in lettuce shoots with increasing the level of solar UV radiation. So, lettuce seedlings grown in UV-T showed higher MDA content in shoots than that of lettuce seedling grown in UV- B or UV-L. On the other hand, MDA content in root was higher in lettuce seedlings in UV-B than that of other treatments. MDA content 
reflects the intracellular redox status of the plant tissues during exposure to solar UV. The higher level of MDA could be due to formation of highly reactive oxygen radicals and their reaction products. Two routes for UV -induced formation of reactive oxygen species (ROS) in the cell may be due to: (1) Nonspecific production of ROS during high UV levels as the results of randomly induced chemistry of cellular molecules after absorption of the energy content of the UV quanta. Photosensitizers, such as aromatic amino acids or phenolic compounds, can mediate transfer of the energy to oxygen molecules in their vicinity; (2) Specific UVB-dependent catalytic production of ROS at much lower levels of radiation, forinstance by oxidases or peroxidases (Mikael Brosche'a and Ake Strid 2003).

\section{Solar UV changes the antioxidant defensive enzymes}

Data in Table (3) indicated the differences in antioxidant enzymes activities in shoots and roots of lettuce seedlings grown under different levels of UV solar radiations. The results indicated that shoot peroxidase activity is not affected by the level of UV radiation. While catalase activity was inhibited by high level of UV radiation (in UV-T) and low level of UV radiation (UV-L). On the other hand ascorbate peroxidase activity in shoots of lettuce seedlings grown under high level of solar UV radiation (UV-T) was higher than that in shoots of seedlings grown under UV blocker plastic film (UV-B) or low level of UV solar radiations (UV-L).

In Roots of lettuce seedlings the activities of peroxidase, catalase, and ascorbate peroxidase were increased by increasing the level of solar UV radiations. Whereas, the highest activity of these enzymes were recorded in roots of lettuce seedlings grown under high level of solar UV radiations. While roots of lettuce seedlings grown under UV blocker plastic films showed the lowest antioxidant enzyme activity.

The effects of UV radiation on free radical production and scavenging, as well as on cell membranes in plants, have been well documented (Takeuchi et al 1995; Rao et al 1996; Costa et al 2002). Various environmental stresses cause $\mathrm{H}_{2} \mathrm{O}_{2}$ accumulation in leaves and the regulation of these enhanced $\mathrm{H}_{2} \mathrm{O}_{2}$ levels is of most importance in plant cell metabolism. Hydrogen peroxide, an active oxygen species, is known to diffuse across biological membranes and cause cellular damage. The accumulation of $\mathrm{H} 2 \mathrm{O} 2$ produced an increase in CAT and APX activities in potato tubers during low-temperature storage (Mizuno et al 1998). Studies carried out on rice - Oryza sativa - leaves demonstrated that after supplemental UV-B radiation, CAT and SOD activities were enhanced; meanwhile, no differences were observed in APX (Dai et al 1997). In sunflower cotyledons, the induction of antioxidant enzymes with peroxidase activity (CAT and GPX) indicated that hydrogen peroxide participates actively on UV-B plant response. It has been demonstrated that GPX activity increases under UV-B irradiadion (Rao et al 1996), UV-C treatment (Zacchini and de Agazio, 2004) and salinity (Parida et al 2004), and this increase has been used as an indicator for different abiotic stresses. The fact that GPX was induced with both the UV-B treatments and even more in darkness recovery allows to assume that the photosynthetic electron transport and photophosphorylation allowed the major plant recuperation.

Solar UV radiations accumulate phenols in lettuce shoots and roots

Total phenol content seems to be influenced by UV solar radiation (Table 4). It can be noticed a significant increase in the total phenol content in lettuce shoots grown under high or low level of solar UV (in UV-T and UV- L) compared to shoots grown under UV- blocker plastic films (UV-B). In roots, total phenols significantly increased by exposure to low or high level of solar UV in UV-L or UV-T respectively. UV induces accumulation of secondary metabolites like phenols to protect or develop physiological function. Solar UV radiations stimulate the phenylparpanoid pathway resulting in accumulation of phenols and flavinoids (Day and Vogelmann, 1995). Similar results were reported by Ordidge et al (2010) who suggested that the phenolic compounds are not accumulated as protections against UV damage; instead they may be manifestation of an as yet unspecified adaptive response to undamaging level of UV. Also, the high phenolic contents in lettuce leaves grown under high level of solar UV radiation could play a role in the protection of photosynthetic apparatus against UV damage.

Solar UV radiation induce PAL activity in lettuce seedlings

Phenyl alanin ammonia lyase (PAL) is the key enzyme of phenol biosynthesis. Data in Table (5) indicated that PAL activity in shoots and roots were elevated in lettuce seedlings grown under plastic 
in lettuce (Lactuca sativa)

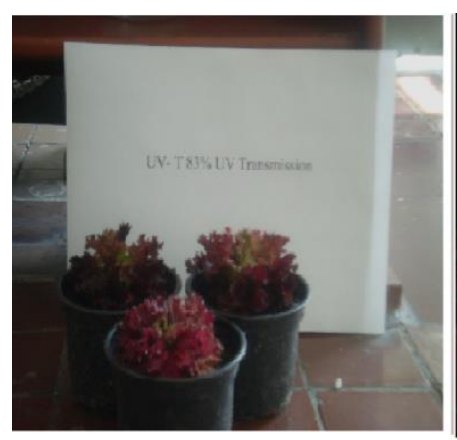

UV-T

$83 \%$ UV transmission

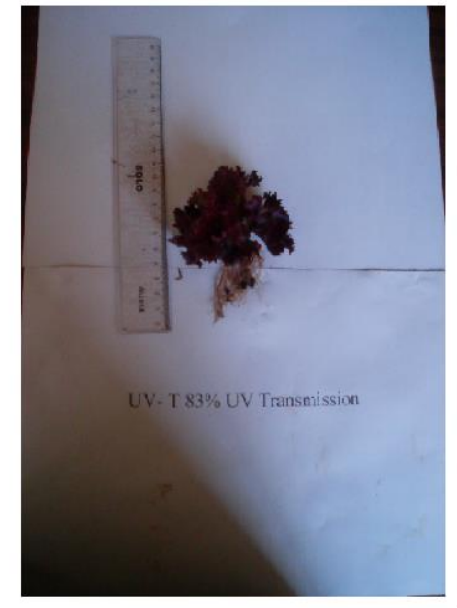

UV-T

$83 \%$ UV Transmission

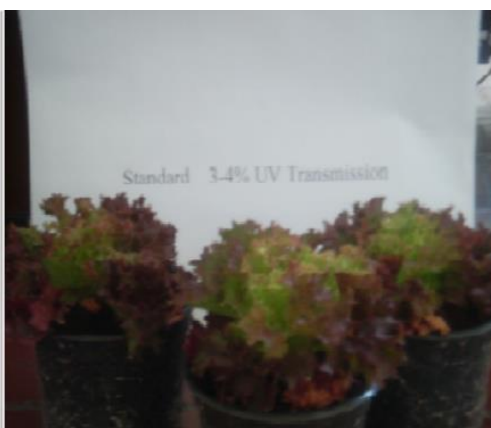

UV-L

4\% UV transmission

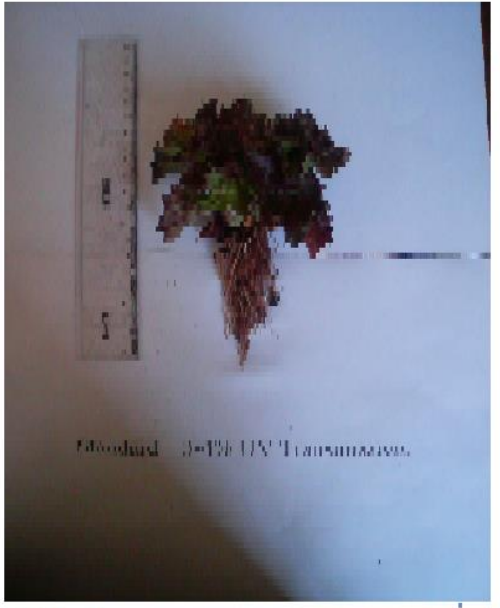

UV-L

4\% UV transmission

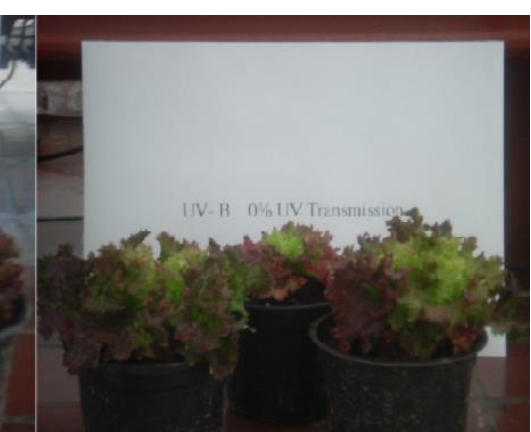

UV-B

0\% UV transmission

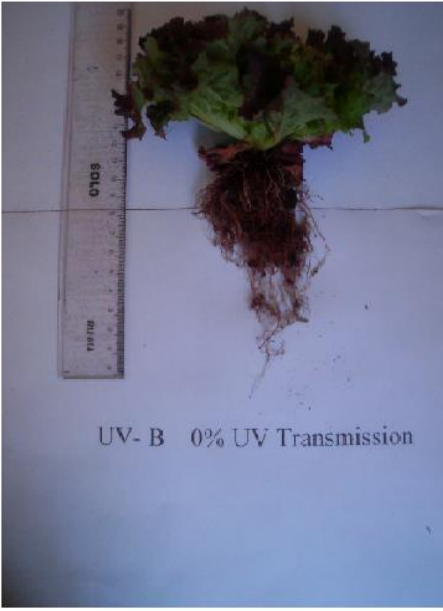

UV-B

$0 \%$ UV transmission

Fig. 1. Effect of different levels of solar UV radiation on the lettuce seedlings growth and development

Table 1. Effect of different levels of UV solar radiation on lettuce seedling growth parameters

\begin{tabular}{|cccc|}
\hline Treatments & Shoot length Cm & Root length Cm & Seedling Fresh weight (g) \\
\hline UV-B & $5.00 \pm 0.06^{\mathrm{a}}$ & $16.50 \pm 3.50^{\mathrm{a}}$ & $17.00 \pm 0.7^{\mathrm{a}}$ \\
UV-L & $4.70 \pm 0.57^{\mathrm{a}}$ & $9.00 \pm 1.00^{\mathrm{b}}$ & $12.66 \pm 0.35^{\mathrm{b}}$ \\
UV-T & $2.83 \pm 0.28^{\mathrm{b}}$ & $5.00 \pm 1.00^{\mathrm{c}}$ & $5.601 \pm 1.28^{\mathrm{c}}$ \\
\hline
\end{tabular}

Each value is the average of five samples \pm SD

Different letters refers to significant differences. 
Table 2. Effect of different levels of UV solar radiation on lipid peroxidation in lettuce seedling

\begin{tabular}{|ccc|}
\hline \multirow{2}{*}{ Treatments } & \multicolumn{2}{c|}{ Lipid peroxidation $(\mu \mathrm{mol} \mathrm{MDA} / \mathrm{g} \mathrm{FW})$} \\
\cline { 2 - 3 } & Shoot & Root \\
\hline UV-B & $0.43 \pm 0.02^{\mathrm{c}}$ & $0.66 \pm 0.03^{\mathrm{a}}$ \\
UV-L & $0.67 \pm 0.01^{\mathrm{b}}$ & $0.46 \pm 0.03^{\mathrm{c}}$ \\
UV-T & $1.04 \pm 0.02^{\mathrm{a}}$ & $0.522 \pm 0.03^{\mathrm{b}}$ \\
\hline
\end{tabular}

Each value is the average of five samples \pm SD.

Different letters refers to significant differences.

Table 3. Effect of different levels of UV solar radiation on some antioxidant enzymes in shoots and roots of lettuce seedlings

\begin{tabular}{|c|c|c|c|c|c|c|}
\hline \multirow[b]{2}{*}{ Treatments } & \multicolumn{3}{|c|}{ Shoot } & \multicolumn{3}{|c|}{ Root } \\
\hline & $\begin{array}{c}\text { Peroxidase } \\
\left(\Delta \text { OD.min }^{-1} \cdot \mathrm{mg}^{-1}\right. \\
\text { protein })\end{array}$ & $\begin{array}{c}\text { Catalase } \\
\text { (IU/mg } \\
\text { protein) }\end{array}$ & $\begin{array}{c}\text { Ascorbic } \\
\text { peroxidase } \\
\left(\left(\Delta \text { OD.min }{ }^{-1} . \mathrm{mg}^{-1}\right.\right. \\
\text { protein })\end{array}$ & $\begin{array}{c}\text { Peroxidase } \\
\text { ( } \begin{array}{c}\text { OD.min } \\
\text { protein })\end{array}\end{array}$ & $\begin{array}{c}\text { Catalase } \\
\text { (IU/mg } \\
\text { protein) }\end{array}$ & $\begin{array}{l}\text { Ascorbic } \\
\text { Peroxidase } \\
\text { (IU/mg } \\
\text { protein) }\end{array}$ \\
\hline UV-B & $27.63 \pm 0.13^{a}$ & $560.62 \pm 13.7^{a}$ & $24.81 \pm 0.34^{b}$ & $133.88 \pm 4.32^{c}$ & $443.79 \pm 5.62^{c}$ & $87.66 \pm 5.33^{c}$ \\
\hline UV-L & $26.84 \pm 0.23^{a}$ & $396.89 \pm 18.9^{b}$ & $22.21 \pm 0.29^{b}$ & $226.43 \pm 7.68^{b}$ & $688.61 \pm 9.62^{b}$ & $150.45 \pm 3.22^{b}$ \\
\hline UV-T & $26.44 \pm 0.24$ a & $373.56 \pm 12.1^{b}$ & $33.75 \pm 1.12^{\mathrm{a}}$ & $343.40 \pm 6.52^{\mathrm{a}}$ & $1097.14 \pm 19.67^{a}$ & $162.92 \pm 6.32^{\mathrm{a}}$ \\
\hline
\end{tabular}

Each value is the average of five samples \pm SD.

Different letters refers to significant differences.

Table 4. Effect of different levels of UV solar radiation on phenolic compounds contents in shoot and root of lettuce seedling

\begin{tabular}{|ccc|}
\hline \multirow{2}{*}{ Treatments } & \multicolumn{2}{c|}{ Phenols (mg/g DW) } \\
\cline { 2 - 3 } & Shoot & Root \\
\hline UV-B & $0.515 \pm 0.07^{\mathrm{c}}$ & $0.119 \pm 0.02^{\mathrm{c}}$ \\
UV-L & $1.17 \pm 0.17^{\mathrm{b}}$ & $0.29 \pm 0.01^{\mathrm{b}}$ \\
UV-T & $5.19 \pm 0.13^{\mathrm{a}}$ & $0.329 \pm 0.04^{\mathrm{a}}$ \\
\hline
\end{tabular}

Each value is the average of five samples \pm SD. Different letters refers to significant differences.
Table 5. Effect of different levels of UV solar radiation on Phenyl alanin ammonia lyase (PAL) activity in lettuce seedling shoot and root.

\begin{tabular}{|c|c|c|}
\hline \multirow{2}{*}{ Treatments } & \multicolumn{2}{|c|}{ PAL Activity (IU / mg protein) } \\
\hline & Shoot & Root \\
\hline UV-B & $1.67 \pm 0.07^{b}$ & $2.34 \pm 0.12^{c}$ \\
\hline UV-L & $1.81 \pm 0.05^{\mathrm{a}}$ & $4.13 \pm 0.23^{b}$ \\
\hline UV-T & $1.94 \pm 0.07^{a}$ & $6.95 \pm 0.43^{a}$ \\
\hline
\end{tabular}

Each value is the average of five samples $\pm S D$. Different letters refers to significant differences 
in lettuce (Lactuca sativa)

film of high or low UV transparency (UV-T or UVL) compared with PAL activity in lettuce seedlings grown under UV blocker plastic film (UV-B). The high content of phenols in UV-T and UV-L could be attributed to the detected high activity of PAL in shoot and roots of lettuce seedlings. Also, Fan et al (2014) reported that enhanced UV-B radiation caused the increase in the flavonoid synthesis by promoting the activities of PAL in soybean seedlings. The results clearly indicated that both high and low level of UV solar radiation are necessary for phenol formation in lettuce leaves. Activation of phenol biosynthesis by UV solar radiation seems to be through increasing of PAL activity and activation of phenylparpanoid pathway.

The above results can conclude that exposure of lettuce seedling to different levels of solar UV radiation caused significant changes in seedling morphology and growth. The morphological alterations could be attributed to significant changes in some antioxidant enzymes, total phenols accumulations and biosynthesis.

\section{REFERENCES}

A.O.A.C. 2000. Official Methods of Analysis of the association of official analytical hemists. $17^{\text {th }}$ Ed. Washington D.C., U.S.A.

Aeby H. 1984. Catalase in vitro. Meth. Enzymol., 105:121-126.

Beauchamp C. and Fridovich I. 1971. Superoxide dismutase: Improved assays and an assay applicable to acrylamide gels. Anal. Biochem., 44: 276-287.

Conner, J.K. and Zangori, L.A. 1997. A garden study of the effects of ultraviolet- $B$ radiation on pollination success and lifetime female fitness in Brassica. Oecologia., III: 388-395.

Corlett, J.E.; Stephen, J.; Jones, H.G.; Woodfin, R.; Mepsted, R. and Paul, N.D. 1997. Assessing the impact of UV-B radiation on the growth and yield of field crops. In: Lumsden PJ (ed) Plants and UV-B: Response to Environmental Change. Society for Experimental Biology seminar series 64, pp 195-212. Cambridge University Press, Cambridge

Costa, H.; Gallego, S.M. and Tomaro, M.L. 2002. Effect of UV-B radiation on antioxidant defense system in sunflower cotyledons. Plant Sci., 162: 939-945.

Dai, Q.; Yan, B.; Huang, S.; Lui, X.; Peng, S.; Miranda, M.L.L.; Chavez, A.Q.; Vergara, B.S. and Olszyk, D.M. 1997. Response of oxidative stress defense systems in rice (Oryza sativa) leaves with supplemental UV-B radiation. Physiol. Plant, 101: 301-308.

Daniel, H.D. and George, C.M. 1972. Peach seed dormancy in relation to indogenous inhibitors and applied growth substances. J. Amer. Soc. Hort. Sci., 97(5): 651-654.

Fan, C.; Hu, H.; Wang, L.; Zhou, Q. and Huang X. 2014. Enzymological mechanism for the regulation oflanthanum chloride on flavonoid synthesis of soybean seedlings under enhanced ultraviolet-B radiation. Environ Sci Pollut Res, 14: 8792-800. doi: 10.1007/s11356-014-2815-x.

Day, T.A. and Vogelmann, T.C. 1995. Alterations in photosynthesis and pigment distributions in pea leaves following UV- B exposure. Physiologia plantarum, 94: 433-440.

Garcia-Macias, P.; Ordidge, M.; Vysini, E.; Waroonphan, S.; Battey, N.H. and Gordon, M.H. 2007. Changes in the flavonoid and phenolic acid contents andantioxidant activity of red leaf lettuce (Lollo Rosso) due to cultivation under plastic films varying in ultraviolet transparency. Journal of Agricultural and Food Chemistry, 55: 10168-10172.

Gram-matikopoulos, G.; Karousou, R.; Kokkini S. and Manetas Y. (1998). Differential effects of enhanced UV-B radiation on reproductive effort in two chemotypes olMentha spicata under field conditions. Aust J. Plant Physiol., 25: 345-351.

Hammer Schmidt, R.; Nuchles, E.M.; Kuc, J. (1982). Association of enhanced peroxidase activity which induce systemic induced resistance of cucumber to colletotrichum lagenarium. Physiol. Plant Pathol., 20: 73-82.

He, C.Y.; Hsiag, T. and Wolyn, D.J. 2001. Activation of defense responses to Fusarium infection in Asparagus densiflorus. European Journal of Plant Pathology,107: 473-483.

Heath, R.L. and Packer, L. 1968. Photoperoxidation in isolated chloroplast: 1 - Kinetics and stiochemistery of fatty acids peroxidation. Arch. Biochem. Biophys., 125:189-198.

Krizek D.T.; Britz, S.J. and Mirecki, R.M. 1998. Inhibitory effects of ambient levels of solar UV$A$ and UV-B radiation on growth of cV. New Red Fire lettuce. Physiologia Plantarum, 103: 1-7.

Lowry, O.H.; Rosebrough, N.J.; Farr, A.L. and Randall R.J. 1951. "Protein measurement with the Folin phenol reagent". J. Biol. Chem., 193(1): 265-75. 
Mark, U. and Tevini, M. 1996. Combination effects of UV-B radiation and temperature on sunflower (Helianthus annuus L., cv. Polstar) and maize (Zea mays L., cv. Zenit 2000) Seedlings. Plant Physiol., 148: 49-56.

Mikael Brosche'a and Ake Strid 2003. Molecular events following perception of ultraviolet-B radiation by Plants. Physiologia Plantarum, 117: 1-10.

Mizuno, M.; Kamei, M. and Tsuchida, H. 1998. Ascorbate peroxidase activity and catalase cooperate for protection against hydrogen peroxide generated in potato tubers during lowtemperature storage. Biochem. Mol. Biol. Int., 44: 717-726.

Morales L.O.; Teglberg, R. and Brosche, M. 2011. Temporal variation in epidermal flavenonoids due to altered solar UV radiation is moderated by leaf position in Betula pendula. Physiologia Plantarum, 143: 261-270.

Nakano, Y. and Asada, K. 1981. Hydrogen peroxide is scavenged by ascorbate-specific peroxidase in spinach chloroplast. Plant Cell Physiol., 22: 867-880.

Ordidge, M.; Gordon, M.H.; Hadley, P.; John, P.; Lovegrove, J.A.; Vysini, E. and Wagstaffe, A. 2010. Phenolic contents of lettuce, strawberry, raspberry, and blueberry crops cultivated under plastic films varying in ultraviolet transparency. Food Chem., 119(3):1224-1227.

Parida, A.K.; Das, A.B. and Mohanty, P. 2004. Defense potentials to $\mathrm{NaCl}$ in a mangrove,
Bruguiera parviflora: differential changes of isoforms of some antioxidative enzymes. J. Plant Physiol., 161: 531-542.

Rao, M.V.; Paliyath, G. and Ormrod, D.P. 1996. Ultraviolet-B and ozoneinduced biochemical changes in antioxidant enzymes of Arabidopsis thaliana. Plant Physiol., 110: 125-136.

Rau, W. and Hoffmann, H. 1988. Die Wirkung von UV-B auf die photoperiodische Steuerung der Blutenbildung. Akad Natursch Landschaftspflege (ANL) Laufener Sem 3: 53-61.

Saile-Mark, M. and Tevini, M. 1997. Effects of solar UV-B radiation on growth, flowering and yield of Central and Southern European bush bean cultivars (Phaseolus vulgaris L.). Plant Ecol., 128: 114-125.

SAS 1996. SAS' Procedure Guide "Version 6.12th Ed.," SAS Institute Inc., Cary, NC, USA.

Soheila A. and Mackerness, H. 2000. Plant responses to ulteraviolet-B (UV-B 280-320 nm) stress: What are the key regulators? Plant growth regulation, 32: 27-39.

Takeuchi, Y.; Fukumoto, R.; Kasahara, H.; Sakaki, T. and Mitsutoshi, K. 1995. Peroxidation of lipids and growth inhibition induced by UV-B radiation. Plant Cell Environ., 14: 566-570.

Zacchini, M. and de Agazio, M. 2004. Spread of oxidative damage and antioxidative response through cell layers of tobacco callus after UV-C treatment. Plant Physiol. Biochem., 42: 445450. 